\title{
Co-operative federalism in
}

Australia - an intellectual resource for Europe? II

\author{
by Justice R S French
}

This two-part article is taken from a lecture given at the Institute of Advanced Legal Studies on February 22, 2006.

\section{THE APPLICATION OF THE REFERRAL POWER}

$\mathrm{S}$ ince federation there have been a number of references of power pursuant to section 51(xxxvii) although it has come into greater prominence more recently not least because of the post-Wakim referrals in relation to corporations law and recent referrals with respect to threats to national security. A complete list of references up till 2001 is set out in the Third Edition of Sawer's The Australian Constitution - (see Annexure 2 at the end of the second part of this article). Referral Acts from the various States have covered, inter alia, meat inspection, state banking, poultry processing, and air navigation. In the area of family law, the artificiality of constitutionally derived distinctions based upon the reservation to State legislatures of powers in relation to child custody, guardianship, access and maintenance was overcome by all States except Western Australia, referring power over these issues to the Commonwealth so that they could be dealt with by the Family Court of Australia. (This was recommended by the Joint Select Committee on the Family Law Act (1980) and effected by the following State legislation: Commonwealth Powers (Family Law Children) Act 1986 (NSW), (Vic); Commonwealth Powers (Family Law - Children) Act 1990 (Qld); Commonwealth Powers (Family Law) Act 1986 (SA) and Commonwealth Powers (Family Law) Act 1987 (Tas)). That is a federal court created by the Commonwealth Parliament. Western Australia being the only State to set up a Family Court under State law was able to take advantage of the autochthonous expedient so that its Court has always been able to exercise both Federal and State jurisdiction. Jurisdictional issues with respect to property disputes remain. There has been no referral of power in that respect (J Crawford Australian Courts of Law 3rd edn (Melbourne: OUP, 1993) 224-26).

An important application of the referral power is the mutual recognition scheme. This was an interesting model of consensus building leading to an important co-operative referral. In 1991, a process of national consultation was promoted by a Commonwealth-State Committee on Regulatory Reform which was set up after the State Premiers' Conference in 1990. A discussion paper was prepared by the Commonwealth-State Committee on Regulatory Reform called "The Mutual Recognition of Standards and Regulations in Australia."

Seminars were held in each capital city. The discussion paper identified the possibility that Australia might have more barriers to trade in goods and services between States and Territories than would exist between the member nations of the European Community. Freedom in interstate trade and mobility of labour and capital would not be achieved if regulatory environments across States and Territories allowed that possibility to exist. The paper observed (at p2):

\section{Mutual recognition of standards and regulations by all States and Territories has the potential to achieve these objectives. \\ Mutual recognition allows all regulations throughout Australia to co-exist while reducing the current adverse impacts of those regulatory differences.}

The Premiers and Chief Ministers met in November 1991 and a formal agreement was signed on behalf of the Commonwealth, the States and the Territories on May 11, 1992. The Mutual Recognition Act 1992 (Cth) was passed as a law of the Commonwealth following referrals of power by the parliaments of New South Wales and Queensland. Each of these referrals was for a fixed period. The matters referred were defined in the referring Acts in terms of "the enactment of an Act in the terms or substantially the terms set out in the Schedule". In each case the proposed Mutual Recognition Bill 1992 (Cth) was scheduled to the State Referring Act. The law passed by the Parliament of the Commonwealth under that referral was adopted by the other States and Territories and last, with historical consistency, by Western Australia. In Western Australia the adoption was effected by section 4(1) of the Mutual 
Recognition (Western Australia) Act 1995 (WA). It was limited to the original Commonwealth Act and any amendments made to it before the State Act received royal assent. The Commonwealth Act is scheduled to the State Act. The State Act also provided that the adoption was to cease at a specified date, defined as February 28, 1998 or such earlier date as might be fixed by proclamation. The State law has subsequently been extended and the adoption of the Commonwealth Act continues in force in Western Australia (See generally, M Bini "Mutual Recognition and the Reference Power" (1998) 72 ALJ 696; EJ Wright "Mutual Recognition and the National Market for Goods" (1993) 78 ABLR 270; Carroll, "Mutual Recognition: Origins and Implementation" (1995) 54 AJPA 35; T Thomas \& C Saunders (eds) The Australian Mutual Recognition Scheme: A New Approach to an Old Problem (Melbourne: Centre for Comparative Constitutional Studies, 1995).

The most important use of the referral power in recent history is that which supported the introduction of the new corporations scheme, post the Wakim decision. It is not necessary for present purposes to refer to the convoluted negotiations and game playing that went on prior to its adoption. Under the new scheme each State referred the text of the Corporations Bill 2001 and the Australian Securities and Investments Commission Bill 2001 to the Commonwealth as the referred "matter" to the extent to which they deal with matters within the legislative powers of the States. Each State also referred:

\section{The formation of corporations, corporate regulation and the regulation of financial products and services ... to the extent of the making of laws with respect to those matters by making express amendments of the corporations legislation.}

The latter reference has effect only to the extent that the matter is not already a subject of Commonwealth power. There is a five year sunset clause for each reference. The references may also be terminated earlier by proclamation of the Governor in Council. In some cases the amendment reference can be terminated separately.

Following the references, the Commonwealth Parliament, relying upon section 51(xxxvii) enacted the Corporations Act 2001 and the Australian Securities and Investment Commission Act 2001. The Commonwealth and the States also entered into an agreement which involved undertakings about the use of the referred matters, specified procedures for the alteration of the statutes and for termination of the references and requires that the operation of the scheme be reviewed every three years. A powerful impetus to the formation of the scheme was the referral agreement made by Victoria and New South Wales directly with the Commonwealth. That agreement left the other States with little option but to go along with referral. Queensland did so. Western Australia joined in following a change of government in that State. South Australia and Tasmania also joined after the
Commonwealth agreed to consider an amendment to the reference limiting the degree to which the power could be used to require persons to incorporate.

More recently, various States have referred power to the Commonwealth to make laws with respect to terrorism. In Western Australia referral was effected by the Terrorism (Commonwealth Powers) Act 2002 (WA) which, although assented to on January 14, 2003 has not yet been fully proclaimed. The Act is in substance a text reference although there is a subject matter flavour about it which may raise interesting questions if the application, in Western Australia, of laws made under the reference ever arises for judicial consideration. The text of what are called the "referred provisions" is set out in Schedule 1 to the Act. It comprises a new Part 5.3 of the Commonwealth Criminal Code. The operative provision of the referring Act is section 4. It refers:

(a) the matters to which the referred provisions relate, but only to the extent of the making of laws with respect to those matters by including the referred provisions in the Commonwealth Criminal Code in the terms, or substantially in the terms, of the text set out in Schedule 1; and

(b) the matter of terrorist acts, and actions relating to terrorist acts, but only to the extent of the making of laws with respect to that matter by making express amendments of the terrorism legislation or the criminal responsibility legislation.

The reference is fixed in time and is also subject to termination by the Governor by proclamation (s 5 ).

\section{CONSTRUCTIONAL QUESTIONS RAISED BY THE REFERRAL POWER}

As appears from the Convention Debates and from subsequent case law and discussion of the referral power, there are a number of unresolved issues about its operation. Some of these issues may offer the sorts of constructional choices which may be determined according to a strict or broad interpretation informed to a lesser or greater degree by the proposition that the constitution does contemplate something which can sensibly be called "co-operative federalism."

At the outset it may be observed that the power is not, in express terms, a power to refer matters. It is a power conferred upon the parliament of the Commonwealth to make laws with respect to matters referred. This has the important consequence that the laws so made are federal laws. The legislative power conferred by section 51 (xxxvii) is subject to the constitution. So constitutional prohibitions will operate with respect to it. Being federal laws, laws made pursuant to section 51 (xxxvii) attract the operation of section 109 in respect of inconsistent State laws. It is noteworthy that the Corporations Law 2001 seeks to overcome the risks of inadvertent inconsistency by 
expressly denying any intention "to exclude or limit the concurrent operation of any law of a State." Under section $5 \mathrm{~F}$ the States may exclude the operation of the Corporations Law in relation to a matter in whole or in part. This is subject to the Commonwealth by regulation countering that exclusion. There are also rollback provisions in sections $5 \mathrm{G}$ and $5 \mathrm{I}$.

A question has been raised in academic commentary about whether a law adopted by a State parliament pursuant to section 51(xxxvii) is also a Commonwealth law (see JA Thomson "Adopting Commonwealth Laws: Section 51(xxxvii) of the Australian Constitution" (1993) 4 PLR 153). The power conferred by section 51(xxxvii) is qualified so as to limit the operation of a law made under it to the referring States and to any States adopting that law. With respect to the contrary view, it is difficult to see how the language of the section could contemplate a law made pursuant to section 51 (xxxvii) somehow changing its character from Federal to State depending upon whether it applied to a referring or an adopting State.

Section 51(xxxvii) does not expressly confer power upon the States to refer matters or adopt laws made under it. Nor does it specify the mechanism by which State parliaments shall refer matters to the Parliament of the Commonwealth or adopt laws made under the referral power. The practice has been to effect such referrals and adoptions by Acts of the State parliaments. The source of the power to refer is to be found either in the State constitutions or, by implication, from the Commonwealth Constitution. This precise question has not fallen for determination. However it certainly seems at least plausible that the power to refer or adopt is a power conferred upon the Parliaments of the various States, as an implied power by the Commonwealth Constitution. Alternatively, it may be that the implication operates upon the constitution of each State by a reading together of section 51(xxxvii) and section 106 of the constitution.

What may be referred is a "matter". In his address "Making Federalism Work: A New Frame of Reference" at the Australian Association of Constitutional Law Seminar in Perth in May 2002 the then Commonwealth AttorneyGeneral, Darryl Williams, said:

Two types of reference are possible: 'subject matter' and 'text' references. An example of the former was reference of the matter of 'air transport' by Queensland to the Commonwealth in 1943 and 1950. The mutual recognition scheme and the corporations law schemes were both examples of 'text' references subject to the amendments reference in the later scheme.

The scope of the "matters referred" in section 51 (xxxvii) was discussed in $R_{v}$ The Public Vehicles Licensing Appeal Tribunal; Ex parte Australian National Airways Pty Ltd 1964) 113 CLR 207. There it was held that the Commonwealth Powers (Air Transport) Act 1952 (Tas) was a valid reference by the parliament of the State of Tasmania to the Parliament of the Commonwealth of a "matter" under section 51(xxxvii). The High Court said (at 224-25):

One contention which can be disposed of at once is that under s 51 (xxxvii) the power to be referred by a State or States must be simply a power to enact a law in the form of a statute which is described and defined just as an act of parliament would be. This argument is apparently derived from the words at the end of paragraph (xxxvii) 'which afterwards adopt the law'. From that it is inferred that the matter referred to the Parliament of the Commonwealth by the Parliament of a State must be the law. This seems to be an entirely erroneous inference without foundation. The law referred to by the last word goes back to the initial words of section 51 - 'the Parliament shall ... have power to make laws for the peace, order and good government of the Commonwealth' and refers to the law made by the Parliament of the Commonwealth in pursuance of a reference of a matter. It seems absurd to suppose that the only matter that could be referred was the conversion of a specific bill for a law into a law.

It may be inferred from that passage that the Court would have little difficulty in upholding the validity of text references notwithstanding the use of the word "matter" in section 51 (xxxvii). If the power were limited to matters referred in terms of defined subjects of legislation only, the political and historical realities of the Australian Federation would result in the reference power being invoked with about the same frequency as constitutional referenda succeed. The text reference mechanism provides safeguards for the States who are not, by their reference, giving the Commonwealth carte blanche to make laws on any aspect of the subject matter referred.

There is an important open question as to whether a reference unlimited in time is irrevocable (see Graham $V$ Patterson (195) 81 CLR 1, Webb J 25; Airlines of NSW V NeW South Wales (1964) 113 CLR 1, 53; R v Public Vehicles Licensing Appeal Tribunal (1964) 113 CLR 207, 226; Sande V Registrar, Supreme Court (Qld) (1996) 64 FCR 123, Lockhart $\mathrm{J}$ 131). However there is little controversy that a referral may be for a fixed period (see Airlines of NSW ibid, Taylor J 38, Kitto J agreeing 30, Windeyer J 53; R Anderson "Reference of Powers by the States to the Commonwealth" (1951) 2 UWAL Rev 1, 7-8; RD Lumb \& GA Moens The Constitution of the Commonwealth of Australia Annotated 5th edn (Sydney: Butterworths, 1995) 283; cf WA Wynes Legislative, Executive and Judicial Powers in Australia 5th edn (Sydney: Law Book Co, 1976) 171). The uncertainty as to whether a reference unlimited in time is revocable will no doubt have the consequence that for the foreseeable future most, if not all, references will contain a sunset clause.

An interesting question arises about what happens to a Commonwealth law passed pursuant to the referral power if referral by the State is terminated, whether according to a self-executing sunset clause or by revocation. Absent any other provisions, it would be expected that such a law 
would continue in force for there is nothing in the grant of the power which makes the laws under it self-terminating upon revocation of the referral. In this respect the position of referring States and adopting States is arguably different. The latter case would depend upon whether the reference in section 51 (xxxvii) to States whose parliaments "afterwards adopt the law" provides for extension of the law to those States only during the currency of the adoption or once and for all after adoption. This would not be a practical problem where referral or adoption involving sunset clauses also provide for self terminating provisions in the laws made pursuant to the referral. Apparently however this is not the case with the Corporations Law.

There is a related question about the basis upon which a law made under a referral may be amended. Where the referral is of a subject matter rather than a precise text then, so long as the referral subsists, there would seem to be little doubt that the Commonwealth could amend laws made pursuant to it provided the amendment did not take the laws outside the scope of the subject matter. The effect of amendment upon the law and States which had adopted the original law rather than referred the subject matter is questionable.

If the Commonwealth were to repeal a law made under a referral the law would also cease to have effect in those States which had adopted it. Amendment of a referred law would require adoption by non-referring States, either of the amendment or of the law as amended if it were to continue to have effect in those States. Absent such adoption, it is arguable that the original unamended version of the law would cease to have effect in nonreferring States.

A mechanism by which referring or adopting States may deter the Commonwealth from non-consensual amendment would be to make the referral or adoption subject to a condition that it would be revoked in the event that the law were amended otherwise than in accordance with some agreed mechanism for obtaining consensus. Even then the question remains about the operation of the original version of the Commonwealth law if the referral or adoption is revoked.

The language of the referral power leaves open the possibility that a Commonwealth law made under it may have application to one or more, but not necessarily all, States of Australia. This possibility does not seem to have been prominent in the consideration of the power during the Convention debates. The spectacle of a kind of Swiss cheese Commonwealth law is not particularly edifying but is plainly open and indeed is a reality under certain of the limited referrals already in place. At one point it was a possibility that a Commonwealth Corporations Law would be enacted which would operate only in certain States. It is difficult enough in a federation to have to deal with State laws which change from one border to the next. The balkanisation of Commonwealth laws should not lightly be accepted. There is a strong argument against the exercise of the power in relation to anything less than a universal referral. That does not mean conferring a veto on idiosyncratic state governments. It requires, however, a recognition that uniformity is a priority goal where the laws of the Commonwealth are concerned.

\section{EXECUTIVE COOPERATION IN A FEDERATION}

Cooperation may be affected through the use of the executive power of the Commonwealth and the States. Joint authorities may be established to carry out particular tasks. Such authorities may involve representation of each of the States and Territories and of the Commonwealth. They may be subject to the approval of a particular ministerial council. One example is the National Transport Commission (NTC) and its predecessor, the National Road Transport Commission (NRTC). The Commonwealth Parliament does not have any specific legislative power over road transport. Such powers lie with the States and Territories. Before the NRTC was set up in 1991, coordination of the regulation of road transport was undertaken through the Australian Transport Advisory Council. The Ministers for Transport of the Commonwealth, the States and the Territories made up that Council. The impetus for the establishment of the NRTC is described in McIntyre and Moore, The National Road Transport Commission: An Experiment in Cooperative Federalism, a paper presented to the Public Law Discussion Group, Faculty of Law, Australian National University on July 17, 2001. The authors of the paper observed:
By the early 1990s, there was a widespread perception that the division of powers under Australia's federal system was acting as an impediment to economic efficiency and that this impediment had to be addressed to enable Australia to maintain a competitive position in an increasingly difficult world economic environment. At this time there was a perception in the road transport industry and amongst transport policy makers that the efficiency of road transport was impeded as it was a national industry suffering from differential regulatory treatment by States and Territories.

Some of the differences pointed out by the authors included standards for heavy vehicles, including their weights and dimensions, permitted hours of driving, work and vehicle charges. The NRTC was established in January 1992, and operated under a Commonwealth Statute, the National Road Transport Commission Act 1991 (Cth), and intergovernmental agreements known as the Heavy Vehicles Agreement and the Light Vehicles Agreement are attached as schedules to that Act.

In January 2004, under the National Transport Commission Act 2003 (Cth), the NTC replaced the NRTC. The establishment of the NTC similarly relied upon a Commonwealth statute and an inter-governmental agreement, the Inter-Governmental Agreement for 
Regulatory and Operational Reform in Road, Rail and Intermodal Transport, also signed by the Commonwealth, State and Territory Transport Ministers as members of the Australian Transport Council. As the titles of the Act and agreement suggest, the new Commission's charter is broader than its predecessor's; in addition to its regulatory and reform roles in relation to road transport, the NTC also undertakes regulatory and reform functions in relation to rail and intermodal transport.

There are a large number of Acts of Parliament which allow arrangements to be made between Commonwealth and State governments to give effect to the statute or to confer functions or duties on officers of the other jurisdictions. One area of executive cooperation that has generated some difficulty is the conferring on Commonwealth officers of duties under State law. Under the old Corporations Law of the States, breaches of the law were to be prosecuted by the Commonwealth Director of Public Prosecutions. In $R_{v}$ Hughes (2000) 202 CLR 535, the High Court held that a State Parliament does not have power to invest functions in Commonwealth officers directly. However the Commonwealth Parliament can through its incidental legislative power allow Commonwealth officers to carry out functions and accept appointments in addition to their Commonwealth office. The High Court, however, would have held invalid a provision of a State law purporting to impose a duty upon a Commonwealth officer.

\section{JUDICIAL COOPERATION}

The area of co-operative federalism in respect of the judiciary has already been mentioned in the context of Chapter 3 of the constitution which expressly permits the Commonwealth Parliament to confer federal jurisdiction on State courts. There is no equivalent provision allowing State legislatures to confer jurisdiction on Federal courts to deal with matters of state law. There is nevertheless still ample room for cooperation within the judiciary. There have been instances in which members of one State Supreme Court have sat as temporary members of another. In a recent case involving an appeal to the New South Wales Court of Appeal in which Justice Heydon, formerly of that Court, was named as a respondent, Chief Justice Malcolm of the Supreme Court of Western Australia sat with Justice McPherson of the Queensland Court of Appeal and Justice Ormiston of the Victorian Court of Appeal to constitute a special bench of the New South Wales Court of Appeal. When Justice Ipp of the Western Australian Supreme Court was seconded to the New South Wales Court of Appeal for 12 months, judges of that Court visited Western Australia to sit on appeals in the Supreme Court of this State.

There have been in the past exchanges between the Supreme Court of New South Wales and the Supreme Court of the Northern Territory. In 2005 the Magistrates Courts in Tasmania and the Northern Territory initiated an exchange scheme in which a magistrate from Tasmania sat for six months in the Northern Territory and vice versa.

Judicial exchanges between entities in a federation can be a useful means of overcoming judicial parochialism within those entities. It encourages a sense of national participation by judges who might otherwise be geographically confined. For these and other reasons I have recently proposed to the Judicial Conference of Australia the establishment of a comprehensive judicial exchange scheme in the Commonwealth (see R French, "Judicial Exchange - Debalkanising the Courts", (2006) 15 JJA 142). Canadian Provincial judges have proposed a comprehensive exchange scheme of their own but it is yet to be implemented.

The European Parliament and Council have attached considerable importance to judicial exchange programs as part of a wider strategy for training judges of the Member States of the European Union. A pilot project was created by the European Parliament for 2004 and 2005. Its stated purposes are:

1. To develop exchanges between members of the judiciary in order to enhance the level of mutual confidence and to facilitate mutual recognition of decisions within the European Union.

2. To increase judicial awareness of EU instruments on judicial cooperation in civil and criminal matters by development e-learning tools.

3. To develop contacts and networking between national institutions in charge of training of the judiciary.

The mechanisms for achieving these outcomes are exchanges of judges based on individualised training schemes, e-learning facilities to increase knowledge of EU instruments in criminal and civil matters and meeting officials responsible for training institutions (see http//www.europa.eu.int/comm./justice-home/funding/ civil-cooperation/funding-civil-cooperation-eu.html).

The proposed Work Program for 2005 sets out objectives which have some resonance with the objectives of an Australian judicial exchange system suggested earlier in this paper. Judicial exchange is said in the Work Program to be:

\section{... aimed at enhancing their knowledge of each other's judicial procedures and their awareness of belonging to a common area.}

The utmost importance is placed on the development of "mutual trust between the judicial authorities in the Member States, who must be closely involved in each stage of the project." It is said:

Ultimately these exchanges should lead to an enhancement in mutual trust between judges as well as judicial authorities, the setting up of cross-border networks and partners, a greater 
understanding of each others' systems and a greater knowledge of European Community and/or Union legislation.

The Work Program, which is expressed at a level of generality no doubt appropriate to its application to a variety of Member States with much greater diversity in their judicial and legal systems than exists between the States of Australia, does not spell out with precision how judicial exchange involving work in national courts would operate. It sets out, as an initial requirement, identification of the statutory framework of exchanges and "the legal framework for participation by judges and public prosecutors in the work of national jurisdictions ..."

It can be seen from the preceding examples that the idea of judicial exchange in its various manifestations is not novel, although it appears to be relatively recent even when regard is had to the experience of other countries.

The use of judicial exchange, whether by exchange sittings or the lesser option of inter-jurisdictional visitation, can be a powerful influence in the development of a sense of collegiality between judges and courts and at a national level.

\section{CONCLUSION}

It is a striking feature of the Australian Federation today that despite the frictions which exist between the Commonwealth and the States from time to time, there is an increasing incidence of sophisticated intergovernmental arrangements which, in a co-operative way, enable the Commonwealth and the States and Territories to address problems of national concern without the risks of constitutional challenge or the uncertain necessities of formal amendments to the constitution. Such consensual arrangements leave room for the pluralism and diversity that can be a benefit of federation by providing opportunities for the cross fertilisation of ideas from one local setting to another.

Nevertheless, it may be that at some time it will be thought appropriate to amend the constitution in such a way as to provide more directly for co-operative arrangements and particularly for State laws conferring functions and duties by arrangement with the Commonwealth, upon Commonwealth officers.

The question whether any of the techniques of cooperative federalism used in Australia may have application for the European Union, which is not a federation, is beyond the scope of this article. It seems at least plausible however, that co-operative federalism is possible independent of specific constitutional authorisation. To that extent its techniques are potentially as applicable in contemporary Europe as they are in Australia.

\section{ANNEXURE 1}

\section{Section 51 - Constitution}

The Parliament shall, subject to this Constitution, have power to make laws for the peace, order, and good government of the Commonwealth with respect to:

(i) Trade and commerce with other countries, and among the States:

(ii) Taxation; but so as not to discriminate between States or parts of States:

(iii) Bounties on the production or export of goods, but so that such bounties shall be uniform throughout the Commonwealth:

(iv) Borrowing money on the public credit of the Commonwealth:

(v) Postal, telegraphic, telephonic, and other like services:

(vi) The naval and military defence of the Commonwealth and of the several States, and the control of the forces to execute and maintain the laws of the Commonwealth:

(vii) Lighthouses, lightships, beacons and buoys;

(viii) Astronomical and meteorological observations;

(ix) Quarantine:

(x) Fisheries in Australian waters beyond territorial limits:

(xi) Census and statistics:

(xii) Currency, coinage, and legal tender:

(xiii) Banking, other than State banking; also State banking extending beyond the limits of the State concerned, the incorporation of banks, and the issue of paper money:

(xiv) Insurance, other than State insurance; also State insurance extending beyond the limits of the State concerned:

(xv) Weights and measures:

(xvi) Bills of exchange and promissory notes:

(xvii) Bankruptcy and insolvency:

(xviii) Copyrights, patents of inventions and designs, and trade marks:

(xix) Naturalization and aliens:

(xx) Foreign corporations, and trading or financial corporations formed within the limits of the Commonwealth:

(xxi) Divorce and matrimonial causes; and in relation thereto, parental rights, and the custody and guardianship of infants:

(xxiii) Invalid and old-age pensions:

(xxiiiiA)The provision of maternity allowances, widows' pensions, child endowment, unemployment, pharmaceutical, sickness and hospital benefits, medical and dental services (but not so as to authorize any form of civil conscription), benefits to students and family allowances: 
(xxiv) The service and execution throughout the Commonwealth of the civil and criminal process and the judgments of the courts of the States:

(xxv) The recognition throughout the Commonwealth of the laws, the public Acts and records, and the judicial proceedings of the States:

(xxvi) The people of any race for whom it is deemed necessary to make special laws:

(xxvii) Immigration and emigration:

(xxviii) The influx of criminals:

(xxix) External affairs:

(xxx) The relations of the Commonwealth with the islands of the Pacific:

(xxxi) The acquisition of property on just terms from any State or person for any purpose in respect of which the Parliament has power to make laws:

(xxxii) The control of railways with respect to transport for the naval and military purposes of the Commonwealth:

(xxxiii) The acquisition, with the consent of a State, of any railways of the State on terms arranged between the Commonwealth and the State: (xxxiv) Railway construction and extension in any State with the consent of that State:

(xxxv) Conciliation and arbitration for the prevention and settlement of industrial disputes extending beyond the limits of any one State:

(xxxvi) Matters in respect of which this Constitution makes provision until the Parliament otherwise provides:

(xxxvii) Matters referred to the Parliament of the Commonwealth by the Parliament or Parliaments of any State or States, but so that the law shall extend only to States by whose Parliaments the matter is referred, or which afterwards adopt the law:

(xxxviii) The exercise within the Commonwealth, at the request or with the concurrence of the Parliaments of all the States directly concerned, of any power which can at the establishment of this Constitution be exercised only by the Parliament of the United Kingdom or by the Federal Council of Australasia:

(xxxix) Matters incidental to the execution of any power vested by this Constitution in the Parliament or in the either House thereof, or in the Government of the Commonwealth, or in the Federal Judicature, or in any department or officer of the Commonwealth.'

ANNEXURE 2

Acts passed by the Parliaments of the States to refer matters to the Parliament under Section 51(xxxvii)

\begin{tabular}{|c|c|c|c|}
\hline State & Number & Short title & How affected \\
\hline \multirow[t]{9}{*}{ New South Wales } & No 65, 1915 & Commonwealth Powers (War) Act 1915 & Expired 9 Jan 1921; see s 5 \\
\hline & No 33, 1942 & Commonwealth Powers Act 1942 & Expired; see s 4 \\
\hline & No 18,1943 & Commonwealth Powers Act 1943 & Expired; see s 4 \\
\hline & No 48, 1983 & Commonwealth Powers (Meat Inspection) Act 1983 & (Still in force) \\
\hline & No 182,1986 & Commonwealth Powers (Family Law - Children) Act 1986 & (Still in force) \\
\hline & No 61, 1992 & Mutual Recognition (New South Wales) Act 1992 & (Still in force) \\
\hline & No 104, 1992 & Commonwealth Powers (State Banking) Act 1992 & (Still in force) \\
\hline & No 100,1993 & Commonwealth Powers (Poultry Processing) Act 1993 & (Still in force) \\
\hline & No 1,2001 & Corporations (Commonwealth Powers) Act 2001 & (Still in force) \\
\hline \multirow[t]{8}{*}{ Victoria } & No 3108 & Commonwealth Powers (Air Navigation) Act 1920 & Repealed by No 4502 \\
\hline & No 3658 & Commonwealth Arrangements Act 1928 (Part III) & Repealed by No 4502 \\
\hline & No 4009 & Debt Conversion Agreement Act 1931 (No 2) & (Still in force) \\
\hline & No 4950 & Commonwealth Powers Act 1943 & $\begin{array}{l}\text { Not proclaimed to come } \\
\text { into operation and cannot } \\
\text { now be so proclaimed }\end{array}$ \\
\hline & No 92, 1986 & Commonwealth Powers (Family Law - Children)Act 1986 & (Still in force) \\
\hline & No 2, 1993 & Mutual Recognition (Victoria) Act 1993 & (Still in force) \\
\hline & No 59, 1996 & Commonwealth Powers (Industrial Relations) Act 1996 & (Still in force) \\
\hline & No 6, 2001 & Corporations (Commonwealth Powers) Act 2001 & (Still in force) \\
\hline
\end{tabular}




\begin{tabular}{|c|c|c|c|}
\hline \multirow[t]{7}{*}{ Queensland } & 12 Geo V No 30 & The Commonwealth Powers (Air Navigation) Act 1921) & Repealed by 1 Geo VI. No 8 \\
\hline & 22 Geo V No 30 & The Commonwealth Legislative Power Act 1931 & Repealed by No 46, 1983 \\
\hline & 7 Geo VI No 19 & Commonwealth Powers Act 1943 & Expired; see s 4 \\
\hline & 14 Geo VI No 2 & The Commonwealth Powers (Air Transport) Act 1950 & (Still in force) \\
\hline & No 37, 1990 & Commonwealth Powers (Family Law - Children) Act 1990 & (Still in force) \\
\hline & No 67, 1992 & Mutual Recognition (Queensland) Act 1992 & (Still in force) \\
\hline & No 43, 2001 & Corporations (Commonwealth Powers) Act 2001 & (Still in force) \\
\hline \multirow[t]{6}{*}{ South Australia } & No 1469,1921 & Commonwealth Powers (Air Navigation) Act 1921 & Repealed by No 2352, 1937 \\
\hline & No 2061,1931 & Commonwealth Legislative Power Act 1931 & (Still in force) \\
\hline & No 3, 1943 & Commonwealth Powers Act 1943 & Expired; see s 5 \\
\hline & No 89, 1986 & Commonwealth Powers (Family Law) Act 1986 & (Still in force) \\
\hline & No 72, 1993 & Mutual Recognition (South Australia) Act 1993 & (Still in force) \\
\hline & No 21, 2001 & Corporations (Commonwealth Powers) Act 2001 & (Still in force) \\
\hline \multirow[t]{9}{*}{ Western Australia } & No 4, 1943 & Commonwealth Powers Act 1943 & Repealed by No 58, 1965 \\
\hline & No 57, 1945 & Commonwealth Powers Act 1945 & Repealed by No 58, 1965 \\
\hline & No 30, 1947 & Commonwealth Powers Act 1943, Amendment Act 1947 & Repealed by No 58, 1965 \\
\hline & No 31, 1947 & Commonwealth Powers Act 1945, Amendment Act 1947 & Repealed by No 58, 1965 \\
\hline & No 73, 1947 & Commonwealth Powers Act 1945, Amendment Act (No 2) & \\
\hline & & 1947 & Repealed by No 58, 1965 \\
\hline & No 81,1947 & $\begin{array}{l}\text { Commonwealth Powers Act 1945-1947, Amendment } \\
\text { (Continuance) Act } 1947\end{array}$ & Repealed by No 58, 1965 \\
\hline & No 53, 1995 & Mutual Recognition (Western Australia) Act 1995 & (Still in force) \\
\hline & No 7, 2001 & Corporations (Commonwealth Powers) Act 2001 & (Still in force) \\
\hline \multirow[t]{7}{*}{ Tasmania } & 11 Geo V No 42 & Commonwealth Powers (Air Navigation) Act 1920 & $\begin{array}{l}\text { Repealed by } 1 \text { Geo VI. } \\
\text { No } 14\end{array}$ \\
\hline & No 46, 1952 & Commonwealth Powers (Air Transport) Act 1952 & (Still in force) \\
\hline & No 62, 1966 & Commonwealth Powers (Trade Practices) Act 1966 & Expired; see s 2 \\
\hline & No 5, 1987 & Commonwealth Powers (Family Law) Act 1987 & (Still in force) \\
\hline & No 33, 1993 & Mutual Recognition (Tasmania) Act 1993 & (Still in force) \\
\hline & No 20, 1994 & $\begin{array}{l}\text { Commonwealth Powers (Family Law) Amendment Act } \\
1994\end{array}$ & (Still in force) \\
\hline & No 39, 2001 & Corporations (Commonwealth Powers) Act 2001 & (Still in force) \\
\hline
\end{tabular}

\section{Justice R S French}

Federal Court of Australia; former Inns of Court Fellow, Institute of Advanced Legal Studies 